\title{
Application of Zirconia in Dentistry: Biological, Mechanical and Optical Considerations
}

\author{
Cláudia Ângela Maziero Volpato1 ${ }^{1}$ Luis Gustavo D’Altoé Garbelotto¹, \\ Márcio Celso Fredel ${ }^{2}$ and Federica Bondioli ${ }^{3}$ \\ ${ }^{1}$ Department of Dentistry - Federal University of Santa Catarina \\ ${ }^{2}$ Department of Mechanical Engineering - Federal University of Santa Catarina \\ ${ }^{3}$ Department of Materials and Environmental Engineering - University of Modena and \\ Reggio Emilia \\ 1,2Brazil \\ ${ }^{3}$ Italy
}

\section{Introduction}

With the aim of replacing the infrastructure of metallic dental prostheses, structural ceramics have been improved and have become increasingly more popular in dentistry. Among the dental ceramics, zirconia has emerged as a versatile and promising material because of its biological, mechanical and optical properties, which has certainly accelerated its routine use in CAD/CAM technology for different types of prosthetic treatment.

Zirconia based ceramics are routinely used in structural applications in engineering, such as in the manufacture of cutting tools, gas sensors, refractories and structural opacifiers. (Rashad \& Baioumy, 2008). To meet structural demands, zirconia is doped with stabilizers to achieve high strength and fracture toughness. (Kelly \& Denry, 2008). The bioceramics that are currently used in medical and dental care are derived from structural materials used in aerospace and military armor, which were modified to suit the additional requirements of biocompatibility. (Thompson et al., 2007; Vagkopoulou et al., 2009).

\section{Structural bioceramics based in zirconia}

\subsection{Zirconia}

Zircon is a shiny gray-white metal, which may look blue-black when in powder form. Zirconia is an oxide which has a high tensile strength, high hardness and corrosion resistance. It is not found as a pure oxide in nature. The main sources of zirconium are zirconate $\left(\mathrm{ZrO}_{2}-\mathrm{SiO}_{2}, \mathrm{ZrSiO}_{4}\right)$ and baddelyite $\left(\mathrm{ZrO}_{2}\right)$, and most of the material used is chemically extracted from these two minerals. The zirconate is more abundant, but less pure, requiring significant processing to get zirconia. (Picone \& Maccauro, 1999). Baddelyite already contains levels of zirconia ranging from $96.5 \%$ to $98.5 \%$. As this mineral shows significant levels, it is known as a source of extreme purity in obtaining zirconium metal and its compounds. Zirconium dioxide $\left(\mathrm{ZrO}_{2}\right)$ resulting from baddelyite, which is also known as 
zirconia, is a course oxide that presents a monoclinic crystal structure at room temperature. However, the powder can be purified and processed synthetically at high temperatures, forming a cubic structure called cubic zirconia. The resulting material is hard, optically flawless and translucent, usually used for making precious stones or gas sensors, P. ex. (Koutayas et al., 2009).

\subsection{Phases of zirconia (monoclic, tetragonal and cubic)}

The spatial arrangement of the atoms in zirconia is characterized by distinct crystallographic structures, characterizing a property known as polymorphism. Its three phases, or crystal structures, are characterized by specific geometry and dimensional parameters: monoclinic, tetragonal and cubic. (Fig. 1a,b,c). Pure zirconia has a monoclinic structure at room temperature, which is stable up to $1170^{\circ} \mathrm{C}$. Between this temperature and $2370^{\circ} \mathrm{C}$, tetragonal zirconia is formed, while cubic zirconia is formed at temperatures above $2370^{\circ} \mathrm{C}$. After processing, and depending on the cooling process, the tetragonal phase becomes monoclinic at about $970^{\circ} \mathrm{C}$. Due to polymorphism, pure zirconia cannot be used at elevated temperatures due to a large volume change (3-5\%) which occurs during cooling to the monoclinic phase. This change is sufficient to exceed the elastic and fracture limits, resulting in cracks and flaws in ceramics. (Denry \& Kelly, 2008).

The transformation of the tetragonal to monoclinic phases can be employed to improve the mechanical properties of zirconia, especially its tenacity. The mechanism involved is known as a booster from transformation. This transformation is martensitic in nature, therefore, a process that occurs by shear without diffusion, ie the atomic position change occurs abruptly at a speed close to the speed of sound propagation in solids. The reverse transition, ie the monoclinic > tetragonal transformation and occurs at approximately $1170^{\circ} \mathrm{C}$, while the tetragonal $>$ monoclinic transformation, which occurs during cooling, is observed between 850 and $1000^{\circ} \mathrm{C}$, depending on the strain energy. Therefore, the manufacturing of components of pure zirconia is not possible due to spontaneous failure. The addition of stabilizing oxides is important because it allows the maintenance of the tetragonal form at room temperature. (Hannink et al., 2000).

Different oxides, such as yttrium oxide $\left(\mathrm{Y}_{2} \mathrm{O}_{3}\right)$, calcium oxide $(\mathrm{CaO})$ or magnesium oxide $(\mathrm{MgO})$, can be added to zirconia to stabilize it, allowing the tetragonal form to exist at room temperature after sintering. The addition of varying amounts of stabilizers allows the formation of partially or fully stabilized zirconia which, when combined with changes in processes, may result in ceramics with exceptional properties such as high flexural strength and fracture toughness, high hardness, excellent chemical resistance and good conductivity ions. A fully stabilized zirconia is obtained by adding sufficient amounts of stabilizing oxides, such as $16 \mathrm{~mol} \%$ magnesia $(\mathrm{MgO}), 16 \mathrm{~mol} \%$ of limestone $(\mathrm{CaO})$ or $8 \mathrm{~mol} \%$ yttria $\left(\mathrm{Y}_{2} \mathrm{O}_{3}\right)$. Since the partial stabilization of zirconia is obtained with the same oxides, but in smaller amounts (eg $2 \mathrm{~mol} \%$ to $3 \mathrm{~mol} \%$ yttria), a multiphase structure is created, which usually consists of tetragonal and cubic zirconia majority / monoclinic precipitated in small amounts. (Picone \& Maccauro, 1999). The transformation of tetragonal zirconia into monoclinic is a phenomenon influenced by temperature, vapor, particle size, micro-and macrostructure of the material, and also by the concentration of stabilizing oxides. The critical particle size for the partially stabilized zirconia to be maintained in the tetragonal form at room temperature is $0.2 \mu \mathrm{m}$ to $1 \mu \mathrm{m}$ (for compositions ranging from $2 \%$ to $3 \mathrm{~mol} \%$ yttria), because, under 0.2 micrometres, the transformation to the monoclinic phase is not possible. (Kelly \& Denry, 2008). 


\subsubsection{Monoclinic zirconia}

The natural form of zirconia, known as baddelyite, contains approximately $2 \% \mathrm{HfO}_{2}$ (hafnium oxide), which is very similar to zirconia in structure and chemical properties. $\mathrm{ZR}_{4}+$ ions have a coordination number of seven for the oxygen ions occupying tetrahedral interstices, with the average distance between the zirconia ion and three of the seven oxygen ions is $2.07 \AA$. Since the average distance between the zirconium ion and four oxygen ions is $2.21 \AA$, in the structure, one of the angles $\left(134.3^{\circ}\right)$ differs significantly from the tetrahedral value $\left(109.5^{\circ}\right)$. Thus, the structure of the oxygen ion is not planar and a curve occurs in the plane of the four oxygens, and the plane of three oxygens is completely erratic. (Hannink et al., 2000)

\subsubsection{Tetragonal zirconia}

Zirconia in its tetragonal phase has the form of a straight prism with rectangular sides. Ions $\mathrm{ZR}_{4}+$ have a coordination number of eight, where the shape once again appears distorted due to the fact that four oxygen ions are at a distance of $2.065 \AA$ in the form of a tetrahedron plan, and four others are at a distance of $2.455 \AA$ in a tetrahedron that is elongated and rotated $90^{\circ}$. (Vagkopoulou et al, 2009).

\subsubsection{Cubic zirconia}

The structure of cubic zirconia can be represented by a simple cubic lattice with eight oxygen ions, which are surrounded by a cubic arrangement of cations, known as fluorite, ie the oxygens occupy the tetrahedral interstices of a cubic lattice (CFC) of cations. (Vagkopoulou et al, 2009).

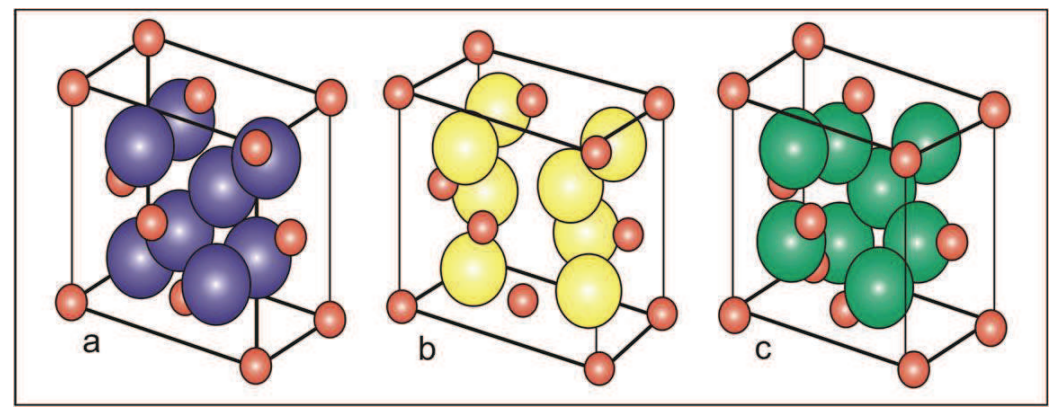

Fig. 1. Crystal structure of monoclic (a), tetragonal (b) and cubic zirconia(c). Source: (Hannink et al., 2000)

\subsection{Technology of powder (powder size and morphology)}

The increasing use of ceramics in more advanced technological applications has resulted in a heightened demand for improvements in properties and reliability. (Lange, 1989). In the last decades is has been the realized that such improvements can be achieved only through careful attention not only to the chemical and mineralogical composition but also to the fabrication process. (Rahaman, 1995). The engineering properties of a polycrystalline ceramic are controlled by the microstructure, which depends on the processing method used to fabricate the body. Therefore the microstructures due to the fabrication processes govern the production of an object with the desired properties (Fig. 2). 


\section{Chemical}

composition

\section{Ceramic fabrication}
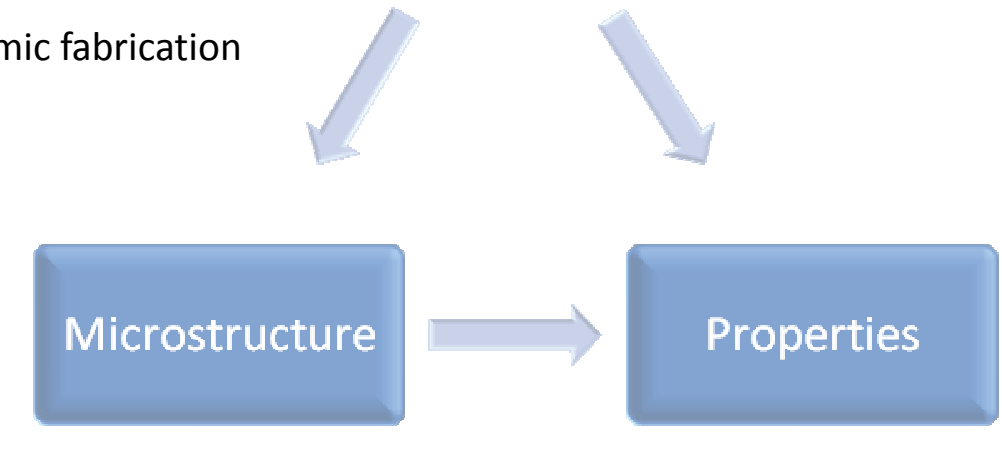

Fig. 2. Relationships in the ceramic fabrication process. Source: Rahaman, 1995

The production of polycrystalline ceramic from powders can be divided in two steps: processes prior to the firing of the green body and processes that occur during firing. The most useful approach requires that close attention be paid to each processing step because each step has the potential for producing undesirable microstructural flaws that can limit the properties and the reliability of the obtained body.

In particular during the last 20-25 years there was a large acceptance that utilization of powders with controlled purity, size and size distribution, shape and degree of agglomeration are required to obtain high quality ceramics. The properties of the starting powders are then determined by the method of their production and many methods are available for the preparation of ceramic powders. Different mechanical mixing (involving the comminution of a coarse, granular material), thermal decomposition, precipitation or hydrolysis and hydrothermal methods have been proposed to fulfill these requirements (Table 1). (Sõmiya \& Akiba, 1999).

The chemical methods, although often more expensive than the mechanical methods, offer in general a strictly control of the powder characteristic (Fig. 3a,b) taking into account all the specific synthesis variables. (Tsukada et al., 1999; Piticescu et al., 2005). In practice, the choice of a powder preparation method will depend on the production cost and the capability of the method to achieve a certain set of desired characteristic. Normally a particle size of less than $\approx 1 \mu \mathrm{m}$ allows the achievement of a high density material within a reasonable time (e.g., a few hours). Whereas a powder with a wide distribution of particle size may lead to higher packing density in the green body, this benefit is usually vastly outweighed by difficulties in the microstructure control during the consolidation step. The large grains coarsen rapidly at the expense of the smaller grains making the control of the grain size impossible. Homogeneous packing of a powder with a narrow size distribution, especially with spherical shape, generally improves the densification step and the microstructure control. 


\begin{tabular}{|l|l|}
\hline Processing route & Synthesis method \\
\hline 1. Thermal decomposition & a. Heating (evaporation) \\
& b. Spray drying \\
& c. Flame spraying \\
& d. Plasma spraying \\
& e. Vapor phase (CVD) \\
& f. Freeze drying \\
& g. Hot kerosene drying \\
& h. Hot petroleum drying \\
\hline 2. Precipitation or hydrolysis & a. Neutralization and precipitation \\
& b. Homogeneous precipitation \\
& c. Coprecipitation \\
& d. Salts solution \\
& e. Alkoxides \\
& f. Sol-gel \\
\hline 3. Hydrothermal & a. Precipitation (coprecipitation) \\
& b. Crystallization \\
& c. Decomposition \\
& d. Oxidation \\
& e. Synthesis \\
& f. Electrochemical \\
& g. Mechanochemical \\
& h. RESA (reactive submerged arc) \\
& i. Hydrothermal + microwave \\
j. Hydrothermal + Ultrasonic
\end{tabular}

Table 1. Processing route and synthesis method used to obtain $\mathrm{ZrO}_{2}$ powders Source: Sōmiya \& Akiba, 1999
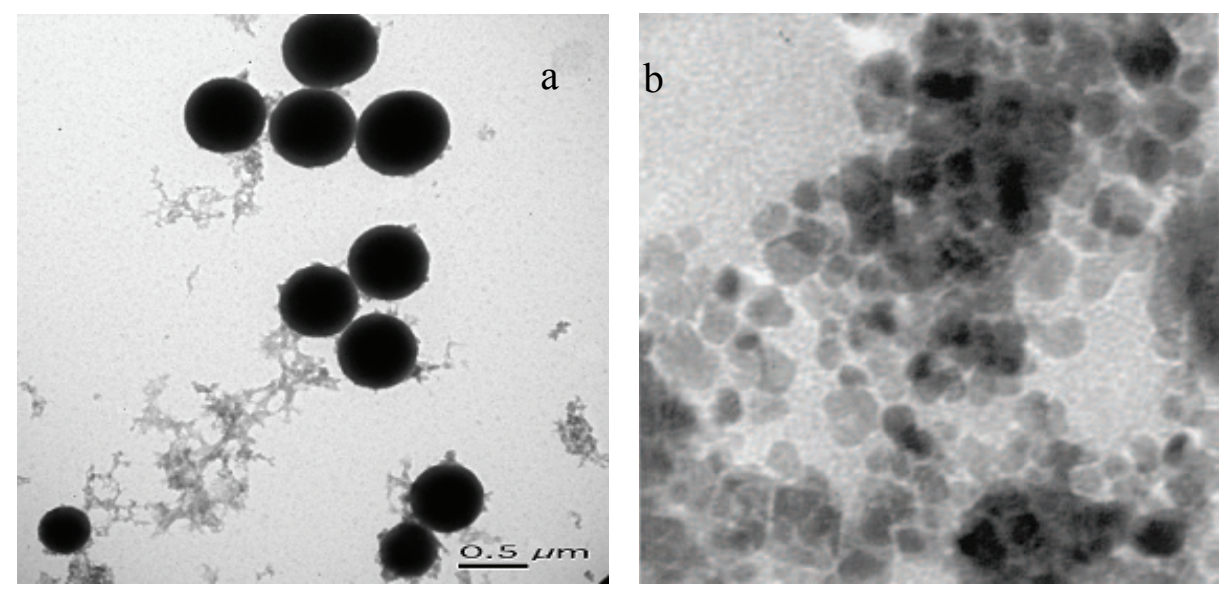

Fig. 3. a,b. An example of a $\mathrm{ZrO}_{2}$ powder prepared by sol-gel method (a) and by microwave assisted hydrothermal method (b). 
Moreover, chemical methods involving chemical reactions under carefully controlled conditions, allow obtaining ultrafine, nanometric powders (grain size below $100 \mathrm{~nm}$ ). With this aim, the so-called wet methods are now the most popular: coprecipitation (Bondioli et al., 2001; Carter et al., 2009), sol-gel (Diaz-Parralejo et al., 2001; Heshmatpour \& Aghakhanpour, 2011), hydrothermal synthesis also supported by microwave radiation (Bondioli et al., 2001; Kanade et al., 2008). The hydrothermal method (hydrolysis) to produce $\mathrm{ZrO}_{2}$-based nanocrystalline powders was first used in 1990. (Sõmiya et al., 1991). Powders with primary particles 20-22 $\mathrm{nm}$ in size and specific surface area 20-95 m²/g were obtained in the $\mathrm{ZrO}_{2}-\mathrm{Y}_{2} \mathrm{O}_{3}\left(0,5.2\right.$, and 13.9 wt. $\left.\% \mathrm{Y}_{2} \mathrm{O}_{3}\right)$ system. The bending strength of materials sintered from these powders varied from 300 to $1000 \mathrm{MPa}$ and critical fracture toughness coefficient from 2.5 to $6.0 \mathrm{MPa} / \mathrm{m}$. Variation in temperature, pressure, synthesis time and chemical composition permits flexible control of the production of practically mono disperse powders with preset particle sizes and crystal structure.

Nanoceramics materials are in the early stages of development but already show many processing and property advantages over conventional coarse grained alternatives. Interest in nanosized ceramic powders for processing of ceramics is motivated by the promise of the improved sinterability at low temperature (below $0.5 \mathrm{Tm}$ ), an increase in toughness due to a reduction in flaw size, and low-temperature superplastic deformation. Properties of nanostructured materials are directly related to their unusual microstructure that features extremely small grains and a large fraction (up to $40 \mathrm{vol} \%$ depending on grain size) of highly disordered interfaces. Grain size dependent properties have been studied intensively in nanostructured ceramics. For example,an increased surface area such that possessed by nanopowders should result in an enhanced densification rate at a given sintering temperature as expected by the Herring's law (Herring, 1950). Indeed it would suggest that full densification should be achievable at much lower sintering temperatures.

Figure 4 shows the relative shrinkage of nanometric $\mathrm{ZrO}_{2}$ and commercial Y-stabilized tetragonal $\mathrm{ZrO}_{2}$ measured by dilatometry. Shrinkage of nanometric $\mathrm{ZrO}_{2}$ starts at $650^{\circ} \mathrm{C}$ and

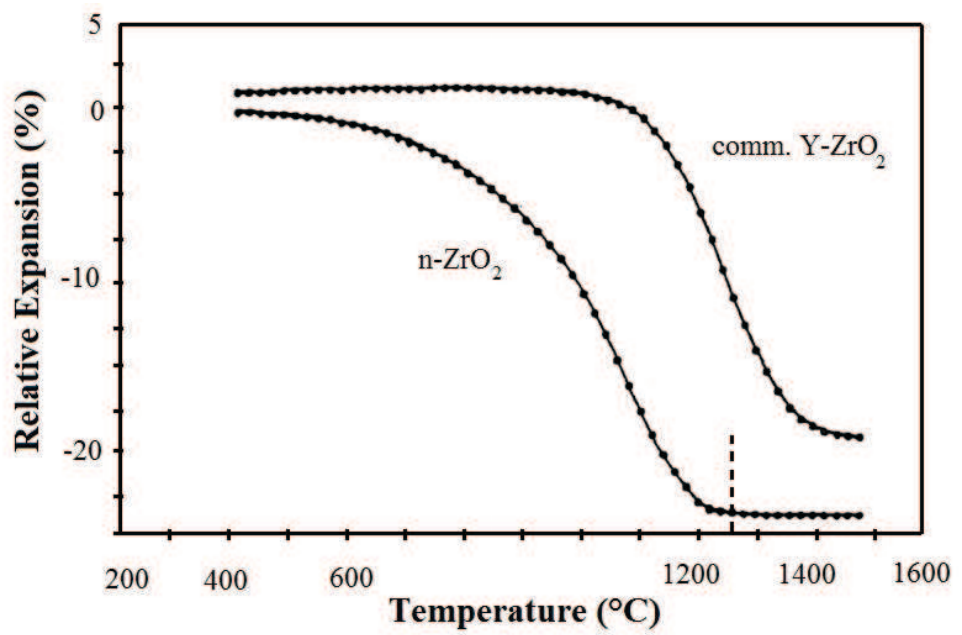

Fig. 4. Relative expansion as a function of sintering temperature for nanostructured and commercial Y-stabilized $\mathrm{ZrO}_{2}$ measured in a dilatometer. The dashed vertical line represents $1 / 2 \mathrm{Tm}$. 
the sample is completely dense at $1200^{\circ} \mathrm{C}$. In the commercial material no densification is observed until $1100^{\circ} \mathrm{C}$ and full density is obtained only above $1400^{\circ} \mathrm{C}$. The sintering temperatures are drastically reduced due to the short diffusion distances in the nanostructured ceramic (pressureless sintering). Experimental evidence shows, moreover, that faster densification rate allow a given density to be achieved at smaller grain size before serious grain growth takes place. (Chen \& Wang, 2000; Mazaheri et al., 2008; Tartaj \& Tartaj, 2009). Success in avoiding the latter is related to control of the competition between densification and grain growth, something that is extremely difficult because the driving forces for both are proportional to the reciprocal grain size and hence comparable in magnitude. A successful approach is the so-called "two steps sintering" (Lin et al., 1997) generally performed by heating the green compacts initially to a high temperature (e.g. 1250 or $1310^{\circ} \mathrm{C}$ ) for a very short time and then cooling it down rapidly to a lower temperature (e.g. $1150^{\circ} \mathrm{C}$ ) where they are held until complete densification is achieved. (Binner \& Vaidhyanathan, 2008). Alternatively, high-density nanostructured ceramic systems including $\mathrm{ZrO}_{2}$ have been achieved by means of pressure-assisted sintering. Applying some pressure during sintering can increase the densification rate and suppress the particle growth. (Madhav Reddy et al., 2010).

Regarding the mechanical properties, the empirical Hall-Petch equation predicts that as the grain size (d) decreases the yield strength increases as given by the following equation, here $\sigma$ is the measured flexural strength, $\sigma_{0}$ is the flexural strength at an infinite grain size, $\mathrm{k}$ is the Hall-Petch constant and $\mathrm{d}$ is the average grain size.

$$
\sigma=\sigma_{0}+k d^{1 / 2}
$$

Figures $5 \mathrm{a}, \mathrm{b}$ shows that the flexural strength decreased monotonically with an increase in average grain sizes for the nanostructured $\mathrm{ZrO}_{2}$ samples (Madhav Reddy et al., 2010) following a Hall-Petch type relationship. However it is obvious that this relationship cannot be extrapolated to arbitrarily small grain size and some form of lower limit to this behavior must exist. It has been observed that even if nanocrystalline materials are inherently stronger than their microcrystalline counterparts, the increment in strength falls below the estimated strength based on the Hall-Petch equation.
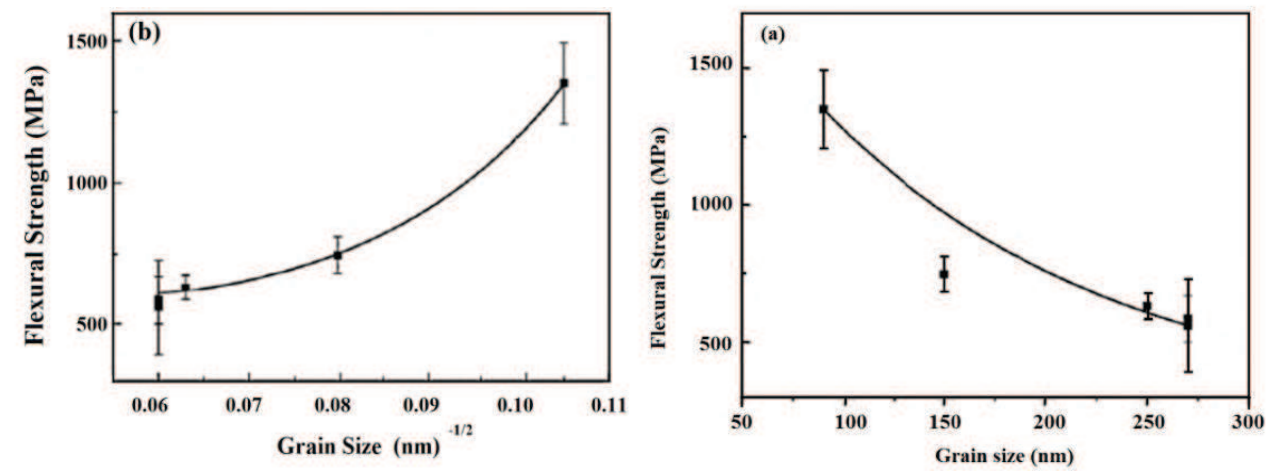

Fig. 5. a,b. Variations of flexural strength with (a) mean grain size and (b) inverse of square root of grain size of $\mathrm{ZrO}_{2}$ samples. Source: Madhav Reddy et al., 2010 
However is important to underline that the consolidation of ultrafine powder is very difficult because of its low apparent density, low flow rate, high contents of absorbed gases and admixtures, high surface area relative to its weight, and severe interparticle friction. Generally, as the size decrease below $\approx 0.5 \mu \mathrm{m}$, the particles exhibit a greater tendency to interact, giving rise to the formation of agglomerates. One consequence of the presence of agglomerates is that the packing of the consolidated powders can be quite non uniform and, during the firing step, little benefit can be obtained over that of a coarse powder. To take advantage of the unique properties of bulk nanocrystalline materials, the nanometer range powders have to be densified with minimal microstructural coarsening and/or undesirable microstructural transformations. However the use of nanopowders requires proper control of the handling and consolidation procedure. The densification process for conventional powders is well known, both theoretically and practically.

\section{Biological characteristics}

\subsection{Biocompatibily and bioinercia}

In vitro and in vivo studies have confirmed a high biocompatibility of zirconia, especially when it is completely purified of its radioactive contents. (Gahlert et al., 2007; Andreiolli et al., 2009). Generally, ceramics are inert materials, which have no adverse local or general tissue reactions. As the ceramic prostheses are made with highly polished surface, they can contact the gum tissue and assist in the maintenance of gingival architecture. Depending on the smoothness, the ceramics prevent the buildup of plaque, creating a favorable surface for the gingival tissues. Zirconia based ceramics are chemically inert materials, allowing good cell adhesion, and while no adverse systemic reactions have been associated with it. (Ichikawa et al., 1992). However, particles from the degradation of zirconia at low temperature (LTD) or from the manufacturing process can be released, promoting an immune localized inflammatory reaction. (Chevalier, 2006).

\subsection{Degree of toxicity}

In vitro tests have shown that zirconia has a lower toxicity than titanium oxide and similar to alumina. Cytotoxicity, carcinogenicity, mutagenic or chromosomal alterations in fibroblasts or blood cells has not been observed. (Vagkopoulou et al., 2009).

\subsection{Radioactivity}

Zirconia is often accompanied by radioactive elements of long half-life, such as thorium (Th) and uranium $(\mathrm{U})$. The separation of these elements is difficult and costly. Two types of radiation are correlated with zirconia, alpha and gamma. Significant amounts of alpha radiation have been observed in zirconia based ceramics used in the manufacture of surgical implants, because, due to their high ionization, the alpha particles destroy cells of hard and soft tissues. As for gamma radiation, the literature suggests that the radiation level is not worrisome in zirconia. (Vagkopoulou et al., 2009).

\section{Mechanical characteristics}

\subsection{Flexural strength}

Flexural strength is an important mechanical property that aids in predicting the performance of fragile materials. It can be defined as the final force required to cause 
fracture and is strongly affected by the size of flaws and defects on the surface of the material tested. (Mecholsky, 1995). Microcracks and defects that inherently grow during the thermal and mechanical processes can significantly influence the measurement of resistance. However, data alone cannot be extrapolated to predict the clinical performance of a material. Resistance values are significant when incorporated into context, through knowledge of the material microstructure, processing history, methodology, test environment and failure mechanisms. Structural failure probabilities are determined by additional failure, variables that describe the stress distribution and sizes of defects, which may be considered as single or multiple failure modes. An understanding of the current clinical failure modes is absolutely necessary before the results of in vitro resistance testing can be considered with clinical validity. (Kelly, 1995). Values of mechanical strength of fragile materials usually exhibit a large dispersion of values (above 50\%), even for highperformance ceramics. (Absi \& Glandus, 2002). This known phenomenon is based on the distribution of defects or failures.

The hypothesis that surface defects and microcracks in ceramic Y-TZP zirconia are made internally on the surface machined by CAD-CAM technique was confirmed by Luthardt et al. (2004). Milling may introduce residual surface compressive stresses that can significantly increase the resistance of zirconia ceramics. On the other hand, severe wear can make profound defects, which act as stress concentrating areas. Alternative methods, such as the partially sintered method of ceramics manufacturing, as well as wear-free procedures, should be developed to obtain crowns and bridges of the Y-TPZ system that increases strength and reliability. Another important fact is that the accumulation of microcracks resulting from loading in an aqueous environment (such as that found in the oral cavity), can cause surface defects that act as enhancers of tension in areas of local concentration, facilitating the initiation of fracture under low level applied stresses. (Lee et al., 2000).

\subsection{Fracture toughness}

Fracture toughness is defined as the level of critical stress at which a particular defect starts to grow. This property indicates the material's ability to resist rapid crack propagation and catastrophic fracture. (Scherrer et al., 1998). It also measures the ease of crack growth from an initial failure. The toughness is determined numerically as the critical value that causes crack extension in the "mode I", ie the opening mode by tension perpendicular to the crack, being designated as KIC. Steel and ductile metals show values above $50 \mathrm{MPa} \mathrm{m} 1 / 2$. Ceramics cover a range of fracture toughnesses which rarely exceeds $5 \mathrm{MPa} \mathrm{m} 1 / 2$. Not surprisingly, these low values affect their clinical performance. (Quinn et al., 2003).

In zirconia, the process of phase transformation induces compressive stress at the crack tip and shear stresses that act against the stress field generated in this region. The addition of an oxide stabilizes the system transformation of zirconia in the tetragonal phase and retains a layer of compressive stresses, resulting in the formation of a tougher stabilized tetragonal zirconia polycrystal. (Kelly \& Denry, 2008).

\subsection{Subcritical crack growth}

The subcritical crack growth (SCG), which consists of a slow propagation of failures, is one of the major causes of damage to ceramics and usually occurs as a function of time. SCG under constant load is due to the corrosive action in the region under stress at the crack tip. Three distinct phases of spreading, designated I, II and III are observed at a velocity curve of 
the crack versus intensity factor of the applied force (V-KI). Region I corresponds to low growth velocities, and gets the most attention of research because it allows the calculation of the survival of the ceramic piece. (Tsalouchou et al., 2008).

The amount of SCG is affected by different factors that add to the strain rates. The format, depth and width of the defects within the material affect the tension intensity factor. In ceramics, the cyclic loading also accelerates the crack propagation and decreases its threshold due to degradation of toughening mechanisms. (Lawson, 1995). A faster spread of the crack is observed in the presence of water, which can be attributed to a high concentration of water molecules around the crack. This environment increases the rate of crack growth because it facilitates the $\mathrm{Zr}-\mathrm{O}-\mathrm{Zr}$ union cleavage at the end of the crack. (Chevalier et al., 1999).

\subsection{Toughening}

The addition of alumina to zirconia Y-TZP provides a material with a higher elastic modulus and finer microstructure, often with greater toughness. The increase in KIC from pure zirconia to composites, for example containing $4 \%$ vol. $\mathrm{Al}_{2} \mathrm{O}_{3}$, is a process based on the toughness of the zirconia grain due to the presence of impurities of alumina at the edges and, consequently, provides an increase in transgranular fracture mode. (Kelly \& Francis Rose, 2002).

In the case of the tetragonal phase, zirconia remains metastable at environmental conditions, meaning that it is theoretically unstable and may persist indefinitely. Thus, the stress field in front of a crack causes these particles to transform into a stable tetragonal monoclinic phase. Following this transformation, there is a slight increase in the volume of the particle and the result is that compressive stresses are set on the surface of the cracks in regions close to their terminus, which tend to throttle and close the cracks, thus preventing their growth. The result is an increase in the toughness of zirconia in the face of this transformation, preventing the propagation of cracks and improving the mechanical behavior of ceramics in the face of tension stresses. (Kelly \& Denry, 2008).

Another toughening mechanism that happens in ceramic materials is crack deflection, which occurs when a crack changes its propagation direction after encountering a particle of the second phase, pore or grain boundaries. In zirconia, the pattern of crack propagation is usually transgranular. An increase of crystalline content present in the fully sintered zirconia equals an increase in the mechanical properties. However, in crystalline materials with the same content, the difference in strength and fracture toughness is related to porosity and effectiveness of each toughening mechanism. (Guazzato et al., 2004).

\subsection{Martensitic transformation}

The characteristic of phase transformations that zirconia suffers is of the martensite type. This phenomenon was named by Osmond, who described the microstructure of a hardened steel and introduced the term 'martensite' (Kelly \& Francis Rose, 2002). In metallurgy, this process is characterized by a transformation that takes place without mass transfer, in a certain range of temperatures and changes the shape of the nucleus. Phase transformations are reversible, and involve the expansion of the core volume by approximately 3 to $4 \%$.

With the stabilization of zirconia by oxides ( $\mathrm{CaO}, \mathrm{MgO}, \mathrm{Y}_{2} \mathrm{O}_{3}, \mathrm{CeO}_{2}$ or other rare earths), tetragonal and cubic phases may be partially or fully stabilized, allowing the determination of mechanical properties necessary for their use. (Tsalouchou et al., 2008). The 
transformation is thermodynamically reversible to $1174^{\circ} \mathrm{C}$ and the change in atomic position shows a curve of thermal hysteresis between heating and cooling cycles. The intensity of the martensitic transformation is influenced by several parameters, such as size, shape and location of the particles of $\mathrm{ZrO}_{2}$ (inter or intragranular), amount of oxide stabilizers, and difference in coefficient of thermal expansion, among others. (Quinn et al., 2003; Kelly \& Francis Rose, 2002).

\subsection{Aging}

Aging or zirconia degradation at low temperature (LTD) is a progressive and spontaneous phenomenon that is exacerbated in the presence of water, steam or fluids. The consequences of the material aging process are many, including surface deterioration, microcracks and decreased resistance in medium and long term periods. Although this degradation has been demonstrated and indirectly associated with a number of flaws in femoral head ceramic prostheses, its relationship does not seem to be clear in predicting failure, due to the absence of rigorous follow up scientific studies to support it. (Denry \& Kelly, 2007).

Aging occurs through a slow surface transformation to the monoclinic stable phase. This transformation begins in individual particles on the surface through a mechanism of stress corrosion. The initial transformation of specific particles can be related to a state of imbalance: greater particle size, lower yttria content, specific guidance from the surface, the presence of residual stress, or even the presence of a cubic phase. The transformation occurs through nucleation and growth processes. This phenomenon leads to a cascade of events occurring in neighboring particles, leading to an increase in volume that stresses the particles and results in subcritical crack growth (SCG), offering a way for water to penetrate inside the material. The stage of growth again depends on various microstructure patterns, such as: porosity, residual stresses, and particle size, among others (Figs. 6 to 8). (Chevalier, 2006).

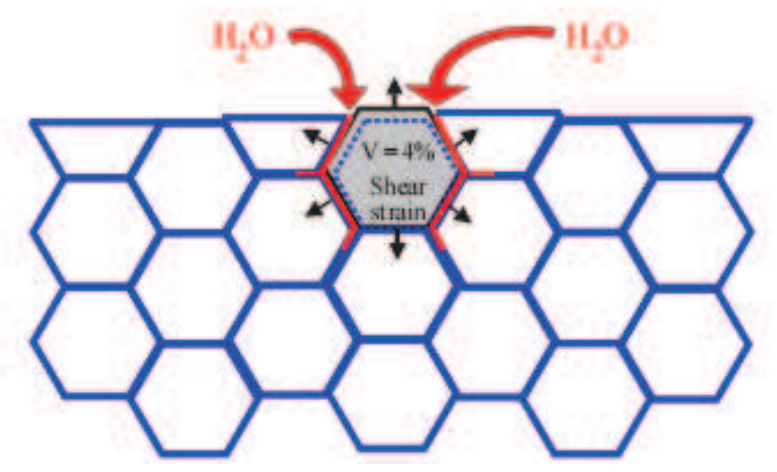

Fig. 6. Diagram of the aging process in cross section. Source: Chevalier, 2006

The attempt to minimize the degradation at low temperature (LTD) of 3Y-TZP includes reducing the particle size, increasing the content of a stabilizing oxide, or even the formation of composites with aluminum oxide $\left(\mathrm{Al}_{2} \mathrm{O}_{3}\right)$. The addition of alumina particles prevents the relaxation of the network of tetragonal zirconia under stress during the aging process, since relaxation is responsible for degradation. (Lee et al., 2000). 


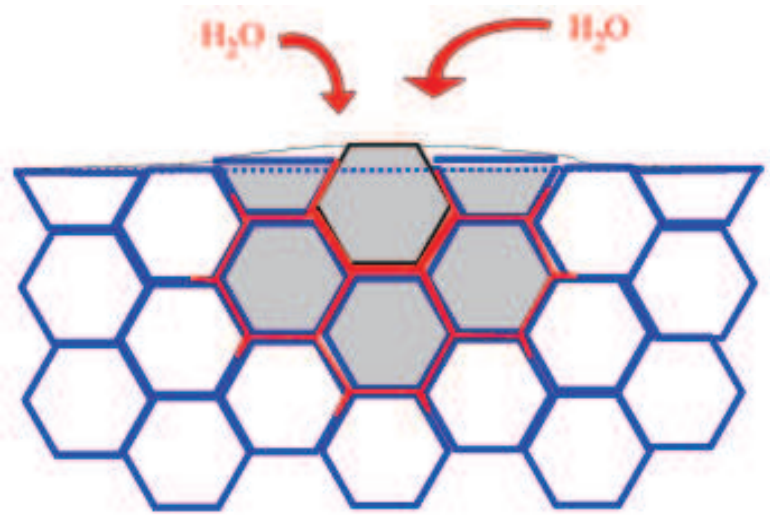

Fig. 7. Nucleation in a specific grain surface, leading to the formation of microcracks and stress on neighboring grains. Source: Chevalier, 2006

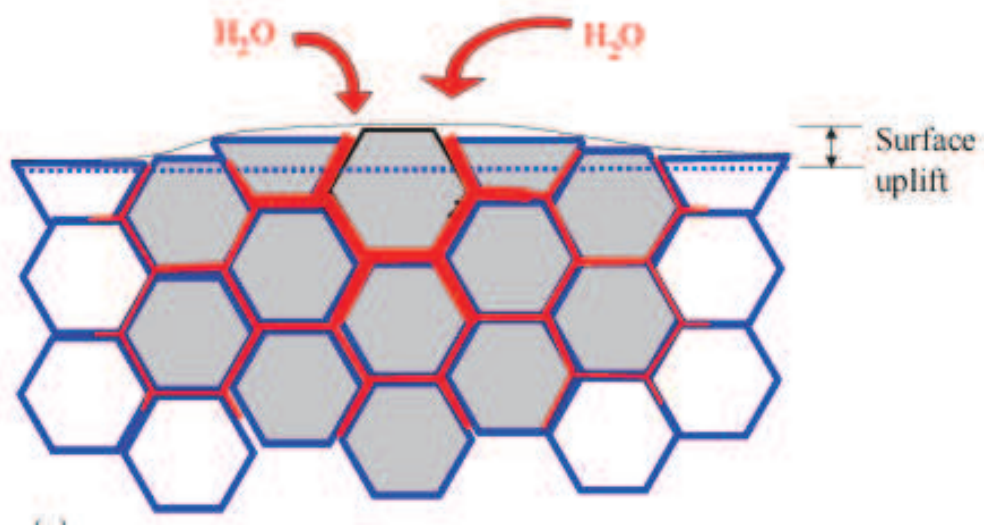

Fig. 8. Growth of the transformed zone, leading to the extensive formation of microcracks and surface roughening. The processed grains appear in gray. The paths in red represent the penetration of water due to the formation of microcracks around the processed grains.

Source: Chevalier, 2006

In the literature, there is a major concern in evaluating the influence of superficial (Ardlin, 2002; Kim et al., 2005) and termic treatments (Tsalouchou et al., 2008) on the mechanical properties of partially stabilized zirconia. Fine polishing of the surface can reduce surface defects created in the finishing, improving the mechanical properties of the surface. However, prior to polishing, surface modifications such as adjustments and finishing, can introduce a compressive surface tension, initially increasing the flexural strength, but then changing the phase integrity of the material and increasing the susceptibility to aging. (Deville et al., 2006). Table 1 summarizes the potential effects of the different stages of processing on the microstructure of zirconia and, consequently, on aging. (Chevalier, 2006). 


\begin{tabular}{|l|l|}
\hline Processing stage & Potential effect to the microstructure \\
\hline Starting powder & $\begin{array}{l}\text { Yttria content and distribution, presence of additives } \\
\text { (leading to secondary phases) }\end{array}$ \\
\hline Training & $\begin{array}{l}\text { Pore distribution of green compacts, and hence porosity of } \\
\text { final components }\end{array}$ \\
\hline $\begin{array}{l}\text { Sintering temperature } \\
\text { and duration }\end{array}$ & Density, particle size, amount of cubic phase \\
\hline sintering & Fractionation step, residual stresses \\
\hline Hot isostatic pressure & $\begin{array}{l}\text { Density, defined microstructure, increasing the } \\
\text { concentration of oxygen gaps, residual stresses }\end{array}$ \\
\hline Whitening & Decrease of oxygen gaps, changes in residual stresses \\
\hline Wear and machining & $\begin{array}{l}\text { Surface roughness, residual stresses, initial monoclinic } \\
\text { content }\end{array}$ \\
\hline Cleaning, sterilization & \begin{tabular}{l} 
Initial content of monoclinic phase \\
\hline
\end{tabular}
\end{tabular}

Table 2. Potential effect of the different stages of processing on the microstructure of ceramics based on zirconia.

\section{Optical characteristics}

\subsection{Degree of opacity and translucency}

The ceramic systems used in dentistry must have adequate translucency to achieve good dental aesthetics while at the same time provide adequate strength during chewing. Considering the currently available ceramic materials, these two properties cannot be obtained by a single material, especially in the manufacturing of fixed prostheses. Thus, an oxide ceramic material should be used as an infrastructure, while a glass or feldspathic ceramic must be used as an esthetic coating material.

The infrastructures of zirconia provide good masking of darkened substrates due to an adequate level of opacity, and they also allow a controlled translucency after lamination, due to their homogeneity and high density (residual porosity $<0.05 \%$ ), even limited in thickness $(0.5 \mathrm{~mm})$. Its opaque optical behavior can be attributed to the fact that the grain size is greater than the length of light, and also that zirconia has a high refractive index, low absorption coefficient and high opacity in the visible and infrared spectrum. (Heffernan et al., 2002a; Denry \& Kelly, 2008). Therefore, zirconia cannot be used as a restorative material alone. Because of its opacity and the current processing technologies, zirconia must be covered with translucent ceramics which exhibit characteristics that may look like natural teeth. (Heffernan et al., 2002b). 
The opacity of zirconia is very useful in clinical situations where polychromatic substrates need to be masked so as not to interfere with the aesthetic result. Blackened teeth, pins and metal cores can be adequately masked by zirconia infrastructures. Through a retrospective of the first zirconia introduced in dentistry (ZTA - alumina matrix strengthened / toughened by zirconia), the opacity of the final prosthetic piece was found to be either similar or higher than metaloceramic crowns. (Heffernan et al., 2002b). This fact, coupled with the difficulty of processing ceramics based on zirconia, boosted research focused on the microstructure and processing of this biomaterial. Changes in size and distribution of grains, methods of obtaining industrial blocks for machining, various additives, stabilizers and pigments have influenced the porosity of the material and therefore its optical behavior, improving its degree of final translucency. (Cho et al., 2009).

Pre-sintered ceramic blocks have been obtained by techniques of industrial forming (isostatic compaction) that have an impact on the final degree of homogeneity and density of the material. (Denry \& Kelly, 2008). Thus, the use of these blocks in machining systems (CAD/CAM) has allowed the construction of a thinner infrastructure $(0.5 \mathrm{~mm})$, due to the high density post-sintering zirconia block, creating more space for the application of a ceramic layer. (Cho et al., 2009; Miyazaki et al., 2009). Zirconia 3Y-TPZ blocks are close to pure white. The main advantage of these blocks is that the white ceramic substrate can be adequately masked. However, an exceedingly white background could compromise the aesthetic outcome of the prosthesis, creating a new substrate that is difficult to be masked by layers of feldpathic or glass ceramic. Solutions such as pre-soaking the sintered infrastructure in solutions based in nanosized pigments of iron oxide or lanthanum has helped in obtaining an infrastructure that is easier to be covered.

\section{Zirconia in dentistry}

The first study on the use of zirconia in dentistry was an assessment on the ceramic surface of metal implants, with the aim of improving their biocompatibility in the oral cavity. Histological examinations revealed fibrointegration of these implants, but with a higher clinical success of those coated with alumina. (Cranin et al., 1975). With the advancement in technology for stabilizing the tetragonal phase at room temperature, and confirming how it was possible to obtain a structurally more tenacious material, several studies were developed by leveraging the use of zirconia as a structural material in dentistry. The first work along these lines studied implants manufactured from the slipcasting process, followed by a superficial treatment with Nd:YAG laser. Thereafter, several studies involving the peri-implant bone remodeling (Miani et al., 1993), the quality of bone apposition directly on ceramic implants (Akagawa et al., 1993), the stability and contour of the mucosa around these implants (Akagawa et al., 1998), the use of a zirconium ceramic based pin in the interior of root canals (Asmussen et al., 1999), prosthetic systems obtained by machining CAD/CAM (Wang et al., 2008) and the construction of abutments on implants (Yildirim et al., 2000) were reported in the literature, reinforcing the viability of this material.

In Prosthetic Dentistry, the introduction of zirconia began with the InCeram Zirconia system (Vita Zanhfabrick, Germany). In this handmade ceramic system, the presence of zirconia resulted in an increase in structural strength of 30 to $40 \%$. Later on, industrial ceramic systems, based on CAD/CAM, allowed the improvement of machining 
techniques for pre-sintered ceramic blocks to obtain infrastructure and prosthetic abutments.

\subsection{Major types of zirconia used in dentistry}

Three different materials were developed for use in dentistry. The first two ceramics are materials with at least two $\mathrm{ZrO}_{2} \mathrm{t}$ - phases as a minor phase (dispersed and precipitated, respectively), and the latter is essentially a $\mathrm{t}-\mathrm{ZrO}_{2}$ (single phase). The origin and details of the stabilization of the tetragonal phase differ among these three toughened microstructures. The three materials share the requirement of stabilizing the tetragonal phase and the toughening involves the martensitic transformation. (Denry \& Kelly, 2008).

\subsubsection{Zirconia toughned alumina (ZTA)}

Ceramics based on zirconia are combined with a matrix of alumina $\left(\mathrm{Al}_{2} \mathrm{O}_{3}\right)$, forming a structure known as ZTA (alumina reinforced with zirconia grains). The stability of the tetragonal phase at room temperature did not initially involve the use of doping, but instead is controlled by the size, morphology and particle localization (intra-or intergranular). In ZTA, particles above a critical size will attain monoclinic symmetry after cooling. Among the dental ceramics, the only commercial example of a toughened ceramic through dispersion is the In-Ceram Zirconia (Vita Zahnfabrik, Germany), which is an interpenetrating composite which was developed with this philosophy, with the addition of $33 \mathrm{~mol} \%$ zirconia stabilized with $12 \mathrm{~mol} \%$ ceria (12Ce-TPZ) to the precursor InCeram Alumina (70 to $80 \%$ aluminum oxide) to be used initially by the craft technique of infiltration slip casting (slipcasting). This technique has a small contraction with sintering; however, the amount of porosities incorporated during the handmade infrastructure has reduced the resistance of prosthetics made with this material. On the other hand, the industrial processing of pre-sintered blocks of the same material results in parts with higher mechanical properties, creating tougher prostheses, but with contractions around $25 \%$ (Wang et al., 2008).

\subsubsection{Mg-PSZ (magnesia partially stabilized zirconia)}

The microstructure of Mg-PSZ consists of an array of cubic zirconia partially stabilized by 8 to $10 \mathrm{~mol} \%$ of magnesium oxide. Due to difficulty in obtaining free silica Mg-PSZ precursors $\left(\mathrm{SiO}_{2}\right)$, magnesium silicates can form a low content of magnesia, favoring the transformation from tetragonal to monoclinic $(t \rightarrow m)$ and resulting in lower mechanical properties and stability of the material. Fully sintered blocks have been manufactured with this material, and require rigid and strong machining systems (Denry \& Kelly, 2008).

\subsubsection{Yttriafullstabilized tetragonal zirconia polycrystal (3Y-TZP)}

The 3Y-TZP consists of an array of partially stabilized zirconia with a $2 \% 4 \mathrm{~mol}$ yttria oxide. In 1977, it was reported that $\mathrm{ZrO}_{2}$ fine grain (usually $<0.5 \mathrm{~mm}$ ) with small concentrations of $\mathrm{Y}_{2} \mathrm{O}_{3}$ stabilizers could contain up to $98 \%$ of the metastable tetragonal phase after sintering. The main feature of this microstructure is to be formed by tetragonal grains of uniform diameter in the order of nanometers, sometimes combined with a small fraction of the cubic phase. As explained above, the YSZ (yttrium oxide) is suitable for optical applications due to its high refractive index, low absorption coefficient and high opacity in the visible and infrared spectrum. 3Y-TZP was first applied in the medical field of orthopedics, with 
significant success due to its good mechanical properties and biocompatibility (Piconi \& Maccauro, 1999). In dental applications, it is fabricated with microstructures containing small grains ( 0.2 to $0.5 \mathrm{~mm}$ in diameter) depending on the sintering temperature, which avoids the phenomenon of structural deterioration or destabilization in the presence of saliva, slowing the growth of subcritical cracks (CST). (Kelly \& Denry, 2008).

Prosthetic restorations with $3 \mathrm{Y}-\mathrm{TZP}$ are obtained by milling pre-sintered blocks, followed by a sintering performed at high temperature, or by machining of sintered blocks completely (Fig 9a,b). The blocks are machined with the aid of CAD/CAM systems, and, in the case of pre-sintered blocks, prosthetic restorations are pre-shaped into a size 25 to $30 \%$ higher than desired (depending on the batch of material) to compensate for the sintering shrinkage. The final sintering temperature is between 1350 and $1550^{\circ} \mathrm{C}$. (Miyazaki et al., 2002). This processing reduces the level of tension present and prevents the transformation from the tetragonal phase to the monoclinic phase $(\mathrm{t} \rightarrow \mathrm{m})$, which leads to a final surface virtually free of the monoclinic phase. Procedures to adjust or sandblast this material should be eliminated to maintain surface integrity and prevent the transformation of $t \rightarrow m$. Infrastructures obtained from these blocks are more stable, have a high crystalline content and a flexural strength around 900 to $1200 \mathrm{MPa}$ (Kelly \& Denry, 2008). The blocks are processed fully sintered by isostatic pressure at a temperature between 1400 to $1500^{\circ} \mathrm{C}$. This process causes the block to have a final density close to $99 \%$, high hardness and low machinability. Thus, machining systems must be robust. (Miyazaki et al., 2002). Restorations produced by these blocks tend to exhibit a large amount of monoclinic zirconia as a function of compression generated by the machining process, which usually results in microcrack on the surface and a susceptibility to degradation at low temperature (CST). Recently, to produce ceramic blocks with greater durability and stability under high temperatures and humid environments, the industry has introduced small amounts of alumina to 3Y-TZP, constituting a variation, called TZP-A. However, a disadvantage of alumina addition is a reduction in the translucency of the block.
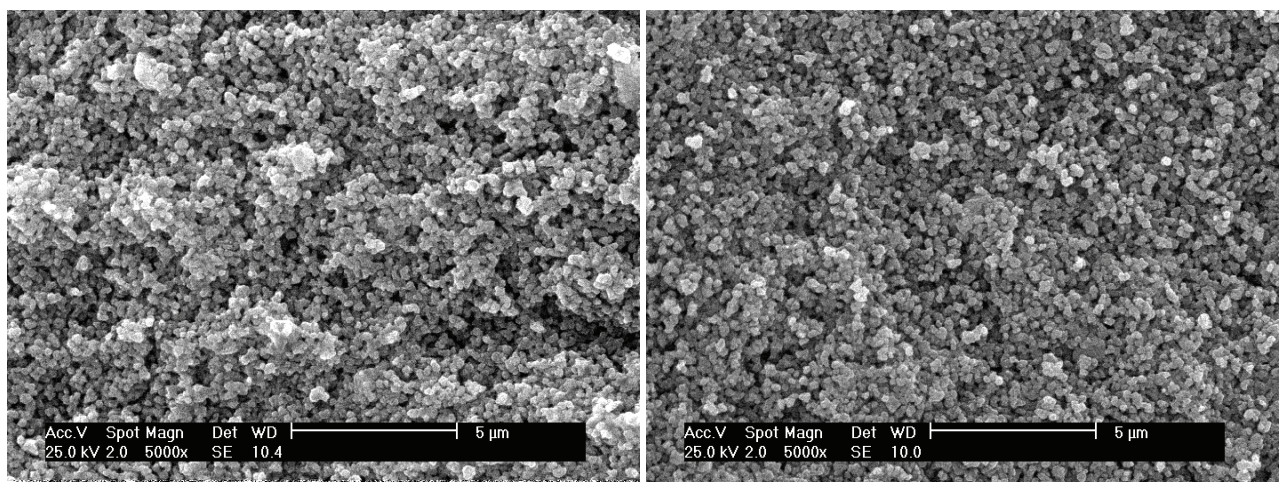

Fig. 8. a,b. Micrographs of different zirconia 3Y-TZP ceramic blocks.

\subsection{Ceramic infrastructure for crowns and bridges 6.2.1 Technique of ceramic infiltration (slipcasting)}

In 1988, Sadoun refined the slipcasting technique to produce a high-strength infrastructure that was named InCeram (Zahnfabrik Vita, Germany). This system has two 
interpenetrated phases: in the first phase, an alumina structure is obtained by the slipcasting process. Later, this structure is manually infiltrated by a thin layer of colored glass (lanthanum glass), granting an increased resistance $(650 \mathrm{MPa})$, and providing the ability to receive a ceramic coating. Three infiltrating systems were developed: strengthening with alumina, zirconia and magnesium. The system InCeram Zirconia is a ceramic body consisting of $67 \%$ aluminum oxide, and the remainder (33\%) is composed of tetragonal zirconium oxide. This mixture provides an increase in tenacity and on the flexural strength of the material $(750 \mathrm{MPa})$. In this system, increasing the final strength is considerable, but a decrease in translucency can be observed, due to the presence of an overly white zirconia, which gives the mix an opacity similar to that of metal-ceramic crowns (Heffernan et al., 2002a,b)

\subsubsection{Compaction technique - CAD/CAM}

This ceramic system was first described in 1993 by Andersson and Oden, and was named All-Ceram Procera (Nobel Biocare, Sweden). With this system, it is possible to fabricate allceramic crowns from an infrastructure of densely sintered and non-porous $(99.5 \%)$ pure aluminum oxide. The powder is compressed into a die refractory in a ceramic processing known as uniaxial vacuum, which supports a sintering of $1550^{\circ} \mathrm{C}$ for $1 \mathrm{~h}$, producing a dense and crystalline infrastructure, with a particle size of $4 \mu \mathrm{m}$ and flexural strength of $600 \mathrm{MPa}$. Afterwards, these infrastructures are tried on clinically, and covered by low-fusing ceramics. The infrastructure can also be obtained with a mixture of alumina and zirconia, through the same process of compression.

Clinical procedures basically consist of obtaining an impression of prepared areas and making models and stone dies. The die is positioned on the rotating platform of a scanner developed for this system. A probe with a spherical sapphire tip performs a global mapping of the die at $360^{\circ}$. The outline of the preparation is registered in three dimensions, reaching 25,000 to 50,000 points. The points obtained are sent to the computer where the operator works on the image generated by the scanner, starting with the identification of the cervical end. After delineating the end, the emergence profile and the thickness of the future infrastructure are defined. Upon completion of the digital design, it is sent via modem to a Production Station (Sandvik AB Estolcomo PROCERA or PROCERA Law Fair USA). With this information, an infrastructure can be made without the presence of the model. It is formed by a compaction process (uniaxial or isostatic) that consists of pressing the powder into a mold, creating a "compressed green" in the desired shape and sufficient strength for handling. It is necessary be careful with the compression to minimize the density gradient, due to the characteristics of the process and the state of powder agglomeration. The compacted infrastructure is then sintered in a vacuum furnace at high temperatures. (Oden et al. 1998).

\subsubsection{Machining technique - CAD/CAM}

Pre-sintered blocks have been introduced in the market to try to correct the deficiencies of the craft systems. (Vagkopoulou, 2009). During the industrial processing, advanced isostatic techniques decrease the concentration of defects within the block, reducing the number of catastrophic failures (Miyazaki et al., 2009). Through the obtained digital design (CAD), usually obtained by a scanner, the system starts turning a CAM ceramic block for 15 to 50 
minutes. The resulting piece is crispy, but most of its outline and adaptation should be checked before being subjected to sintering. Upon being subjected to machining, the parts produced present a negative influence from this process. Systems employing pre-sintered blocks have been used because they seem less machine influenced, because the blocks are more porous. On the other hand, the fully sintered blocks present high hardness, requiring robust devices that will generate more power and thus greater compressive tension on the outer surface of the block, enabling the transformation of the tetragonal to monoclinic phase $(\mathrm{t} \rightarrow \mathrm{m})$. The subsequent sintering of pre-sintered machined infrastructure increases the hardness and fracture toughness. However, repeated heat treatments, in which parts are submitted with an application of feldspathic or glass porcelain, seem to have a negative effect on fracture resistance of the material. (Guazzato et al., 2004).

\subsection{Abutments for implant-supported prostheses}

Intermediaries are devices used to make the connection between the implant and the prosthesis. They can be commercially purchased in a pre-manufactured form or fabricated by laboratory manual systems or CAD/CAM. The intermediaries are mostly used for custom cemented prostheses, since they present a gingival profile already in the intermediary stage, keeping the mucosal and peri-implantar gingival concave architecture. Custom ceramic abutments resulting from the machining of pre-sintered blocks or industrial compression techniques are widely used because they provide good results due to their structural stability. They have been made of alumina, alumina/zirconia or zirconia and are particularly suitable for implant supported restorations located in the anterior maxilla, especially in cases where the gingival margin is very thin, and a dark halo or a shadow under the gum tissue due to the metallic color of the intermediary can compromise the aesthetic outcome of the prosthesis. (Yildirim et al., 2000).

\subsubsection{Degree of cervical adaptation}

As the abutment is in direct contact with the implant platform, this region is a possible area to be colonized by bacteria. Therefore, a misfit between the abutment and the implant can result in bone loss around the implants. Studies have shown that pre-fabricated abutments have a higher degree of adaptation to those manufactured in a laboratory. (Byrne et al.,1998; Vigolo et al., 2006) Another important fact is that the union between metallic implants and ceramic abutments is performed by the interface of different materials. The system of connection between them (eg: a hexagonal metal and a ceramic inner hexagon) is not a mechanically efficient system. Metallic devices are being associated with ceramic abutments so that the connection between the parts is made of metal, with only the support between the implant platform and the abutment being ceramic.

\subsubsection{Flexural strength}

Abutments suffer tensile stresses when subjected to oral function. Metal parts have a higher mechanical strength and deformation capacity when compared with ceramic parts. In different studies, ceramic abutments based on zirconia showed average values of fracture 737.6N (Yildirim et al., 2003), 443.6N (Att et al., 2006), 649N (Sundh \& Sjörgren, 2008) and $740 \mathrm{~N}$ (Kerstein \& Radke, 2008). These results demonstrated that zirconia has a higher resistance to established values for maximum incisal forces reported in the literature $(90 \mathrm{~N}$ to 
$370 \mathrm{~N})$. When noting the findings of a study by Att Wael (2006), ceramic abutments subjected to aging showed the lowest resistance when compared to abutments that were not aged, confirming that, despite the structural potential of zirconia, a probability of failure exists due to the aging and growth of subcritical cracks (SCG).

\subsection{Ceramic implants and osseointegration}

The first attempt to use ceramics in the manufacture of a dental implant was in 1975; however, the first study of implants on zirconia was recorded in 1993, when a group of researchers inserted experimental Y-TPZ implants in the mandible of dogs. (Cranin et al., 1975; Miani et al., 1993). With fluorochrome markers, the authors reported the direct apposition of new bone formation to implants after 120 days from the intervention. Confirming the early findings, several studies have shown that there were no adverse reactions, mutagenic or genetic effects on bone formation, pathologic or peri-implant soft tissue inflammatory states, or the mobility of the implant after installation of the prosthesis. A high proliferation of osteoblasts was also observed, presenting an excellent tissue response and good density of cortical bone newly formed around $97.5 \%$ of the implants after the period of osseointegration. However, despite the initial encouraging results when compared with longitudinal and multicenter studies made with titanium implants, the clinical and laboratory data are scarce for a wide and safe clinical application.

\section{Conclusion}

In dentistry, zirconia has been indicated and used for making crowns, bridges, abutments and implant prosthesis infrastructures. As is well known, dental ceramics are often associated with brittle fractures, due to their low resistance to fracture, which has delayed the routine clinical use of all-ceramic prostheses. The introduction of stabilized zirconia has created a real possibility and promise for the application of ceramics in dental reconstructions. However, the mechanical properties of zirconia are not still great and a suitable processing and clinical application protocol is still not fully known and controlled.

\section{References}

Absi, J.; Glandus, J.C. (2002). Numerical separation of bi-modal strength distribuitions. J Eur Ceramic Soc, Vol. 22, No. 5, (May, 2002) pp. 591-601, ISSN 0955-2219.

Akagawa, Y.; Hosokawa, R.; Sato, Y.; Kamayama, K. (1998). Comparasion between freestanding and tooth-connected partially stabilized implants after two years function in monkeys: a clinical and histologic study. J Prosthet Dent, Vol. 80, No. 5, (Nov, 1998) pp. 551-558, ISSN 0022-3913.

Akagawa, Y.; Ichikawa, Y.; Nikai, H.; Tsuru, H. (1993). Interface histology of unloaded and early loaded partially stabilized zirconia endosseous implant in initial bone healing. J Prosthet Dent, Vol. 69, No. 6, (Jun, 1993) pp. 599-604, ISSN 00223913. 
Andreiolli, M.; Wenz, H.J.; Kohal, R.J. (2009). Are ceramic implants a viable alternative to titanium implants? A systematic literature review. Clin Oral Implants Res, Vol. 20, No. 4, (Sep, 2009) pp. 32-47, ISSN 0905-7161.

Ardlin, B.I. (2002). Transformation toughened zirconia for dental inlays, crowns and bridges: chemical stability and effect of low temperature aging on flexural strength and surface structure. Dent Mater, Vol. 18, No. 8, (Dec, 2002) pp. 590-595, ISSN 0109-5641.

Asmussen, E.; Peutzfeld, A.; Heitmann, T. (1999). Stiffness, elastic limit and strength of newer types of endodontic posts. J Dent, Vol. 27, No. 4, (May, 1999) pp. 75-78, ISSN 0300-5712.

Att, W.; Kurun, S.; Gerds, T.; Strub, JR. (2006). Fracture resistance of single-tooth implantsupported all-ceramic restorations: an in vitro study. J Prosthet Dent, Vol. 95, No. 2, (Feb, 2006) pp. 111-116, ISSN 0022-3913.

Binner, J.; Vaidhyanathan, B. (2008). Processing of bulk nanostructured ceramics. J Eur Ceram Soc, Vol. 28, No. 7, (2008) pp. 1329-1339, ISSN 0955-2219.

Bondioli, F.; Ferrari, A.M.; Corradi, A.B.; (2001). Role of praseodymiun on zirconia phases stabilization. Chem Mater, Vol. 13, No. 12, (Nov, 2001) pp. 4550-4554, ISSN 08974756.

Bondioli, F.; Ferrari, A.M.; Leonelli, C.; Siligardi, C.; Pellacani, G.C. (2001). Microwavehydrothermal synthesis of nanocrystalline zirconia powders. J Am Ceram Soc, Vol. 84, No. 11 (Nov, 2001) pp. 2728-2730, ISSN 0002-7820.

Byrne, D.; Houston F.; Cleary, R.; Claffey, N. (1998). The fit of cast premachined implant abutments. J Prosthet Dent, Vol. 80, No. 2, (Ago, 1998) pp. 184-192, ISSN 0022-3913.

Carter, G.A.; Rowles, M.; Ogden, M.I.; Hart, R.D.; Buckley, C.E. (2009). Industrial precipitaion of zirconyl chloride: the effect of $\mathrm{pH}$ and solution concentration on calcination of zirconia. Mater Chem Phys, Vol. 116, No. 2-3, (Aug, 2009) pp. 607-614, ISSN 0254-0584.

Chen, I.W.; Wang, X.H. (2000). Sintering dense nanocrystalline ceramics without final-stage grain growth. Nature, Vol. 404, No. 9, (Mar, 2000) pp. 168-171, ISSN 0028-0836.

Chevalier, J. (2006). What future for zirconia as a biomaterial? Biomaterials, Vol. 27, No. 4, (Jan, 2006) pp. 535-543, ISSN 0142-9612.

Chevalier, J.; Olangnon, C.; Fantoz, G. (1999). Subcritical crack propagation in 3Y-TPZ ceramics: static and cyclic fatigue. J Am Ceram Soc, Vol. 82, No 11, (1999) pp. 31293138, ISSN 1551-2916.

Cho, M.S.; Yu, B.; Lee, Y.Y. (2009). Opalescence of all-ceramic core and venner materials. Dent Mater, Vol. 25, No. 6, (Jun, 2009) pp. 695-702, ISSN 0109-5641.

Cranin, A.N.; Schnitman, P.A.; Rabkin, S.M.; Onesto, E.J. (1975) Alumina and zirconia coated vitallium oral endosteal implants in beagles. J Biomed Mater Res, Vol. 9, No. 9, (Jul, 1975) pp. 257-262, ISSN 1549-3296.

Denry, I. \& Kelly, J. R. (2008). State of the art of zirconia for dental applications. Dent Mater, Vol. 24, No. 3, (Mar, 2008) pp. 299-307, ISSN 0109-5641. 
Deville, S.; Chevalier, J.; Gremillard, L. (2006). Influence of surface finish and residual stresses on the aging sensitivity of biomedical grade zirconia. Biomaterials, Vol. 27, No. 10, (Apr, 2006) pp. 2186-2192, ISSN 0142-9612.

Diaz-Parralejo, A.; Cuerda-Correa, E.M.; Macias-Garcia, A.; Diaz-Diez, M.A.; SanchezGonzalez, J. (2011). Tailoring the properties of yttria-stabilized zirconia powders prepared by the sol-gel method for potential use in solid fuel cells. Fuel Proces Tech, Vol. 92, No. 2, (Fev, 2011) pp. 183-189, ISSN 0378-3820.

Gahlert, M.; Gudehus, T.; Eichhorn, S.; Steinhauser, E.; Kniha, H.; Erhardt, W. (2007). Biomechanical and histomorphometric comparasion between zirconia implants with varying surface texture and a titanium implant in the maxilla of miniature pigs. Clin Oral Implants Res, Vol. 18, No. 5, (Jun, 2007) pp. 662-668, ISSN 09057161.

Guazzato, M., Albakry, M.; Ringer, S.P.; Swain, M.V. (2004). Strength, fracture toughness and microstructure of a selection of all-ceramic materials. Part II. Zirconia based dental ceramics. Dent Mater, Vol. 20, No. 5, (June 2004) pp. 449-456, ISSN 01095641.

Hannink, R.H.J.; Kelly, P.M.; Muddle, B.C. (2000). Transformation toughening in zirconia containing ceramics. J Am Ceram Soc, Vol. 83, No 3, (Mar, 2000) pp. 461-487, ISSN 1551-2916.

Heffernan, M.J.; Aquilino, S.A.; Diaz-Arnold, A.M.; Haselton, D.R.; Stanford, C.M.; Vargas, M.A. (2002). Relative translucency of six all-ceramic systems. Part I: Core materials. J Prosthet Dent, Vol. 88, No. 1, (Jul, 2002) pp. 4-9, ISSN 0022-3913. (a)

Heffernan, M.J.; Aquilino, S.A.; Diaz-Arnold, A.M.; Haselton, D.R.; Stanford, C.M.; Vargas, M.A. (2002). Relative translucency of six all-ceramic systems. Part II: Core and venner materials. J Prosthet Dent, Vol. 88, No. 1, (Jul, 2002) pp. 10-15, ISSN 00223913. (b)

Herring, C. (1950). Effect of change of scale on sintering phenomena. J Appl Phys, Vol. 21, (1950) pp. 301-303, ISSN 0021-8979.

Heshmatpour, F.; Aghakhanpour, R.B. (2011). Synthesis and characterization of nanocrystalline zirconia powder by simple sol-gel method with glucose and fructose as organic additives. Powder Tech, Vol. 205, No. 1-3, (Jan, 2011) pp. 193-200, ISSN 0032-5910.

Ichikawa, Y.; Akagawa, Y.; Nikai, H.; Tsuru, H. (1992). Tissue compatibility and stability of a new zirconia ceramic in vivo. J Prosthet Dent, Vol. 68, No. 2, (Aug, 1992) pp. 322326, ISSN 0022-3913.

Kanade, K. G.; Baeg, J.O.; Apte, S.K.; Prakash, T.L. Kale, B.B. (2008). Synthesis and characterization of nanocrystallined zirconia by hydrothermal method. Mater Res Bul, Vol. 43, No. 3, (Mar, 2008) pp. 723-729, ISSN 0025-5408.

Kelly, J. R. \& Denry, I. (2008). Stabilized zirconia as a structural ceramic: An overview. Dent Mater, Vol. 24, No. 3, (Mar, 2008) pp. 289-298, ISSN 0109-5641.

Kelly, J. R. (1995). Perspectives on strength. Dent Mater, Vol. 11, No. 2, (Mar, 1995) pp. 103110, ISSN 0109-5641. 
Kelly, P.M.; Francis Rose, L.R. (2002). The martensitic transformation in ceramics-its role in transformation toughening. Prog Mater Sci, Vol. 47, (Mar, 2002) pp. 463-557, ISSN 0079-6425.

Kerstein, R.; Radke, J. (2008). A comparasion of fabrication precision and mechanical reliability of 2 zirconia implant abutments. Int J Oral Maxillofac Implants, Vol. 23, No. 6, (Nov-Dec, 2008) pp. 1029-1036, ISSN 0882-2786.

Kim, B.K.; Bae, H.E.; Shim, J.S.; Lee, K.W. (2005). The influence of ceramic surface treatments on the tensile bond strength of composite resin to all-ceramic coping materials. J Prosthet Dent, Vol. 94, No. 4, (Oct, 2005) pp. 357-362, ISSN 00223913.

Koutayas, S.O.; Vagkopoulou, T.; Pelekanos, S.; Koidis, P. \& Strub, J.R. (2009). Zirconia in Dentistry: Part 2. Evidence-based clinical breakthrough. Eur J Esthet Dent, Vol. 4, No. 4, (Winter, 2009) pp. 348-380, ISSN 1862-0612.

Lange, F.F. (1989). Powder processing science and technology for increased reliability. J Am Ceram Soc, Vol. 72, No. 1, (Jan, 1989) pp. 3-15, ISSN 0002-7820.

Lawson, S. (1995). Environmental Degradation of zirconia ceramics. J Eur Ceram Soc, Vol. 15, No 6, (1995) pp. 485-502, ISSN 0955-2219.

Lee, S.K.; Tandon, R.; Readey, M.J.; Lawn, B.R. (2000). Scratch damage on zirconia ceramics. J Am Ceram Soc, Vol. 83, No. 6, (June, 2000) pp. 1482-1432, ISSN 00027820.

Lin, F.J.T.; De Jonghe, L.C.; Rahaman, M.N. (1997). Microstructure refinement of sintered alumina by a two-step sintering technique. J Am Ceram Soc, Vol. 80, No. 9, (Sep, 1997) pp. 2269-2279, ISSN 0002-7820.

Luthardt, R. G.; Holzhüter, M.; Rudolph, H.; Herold,V. \& Walter, M. (2004). CAD/CAM machining effects on Y-TZP zirconia. Dent Mater, Vol. 20, No. 7, (Sep, 2004) pp. 655662, ISSN 0109-5641.

Madhav Reddy, K.; Mukhopadhyay, A.; Basu, B. (2010). Microstructure-mechanicaltribological property correlation of multi stages park plasma sintered tetragonal $\mathrm{ZrO}_{2}$. J Eur Ceram Soc, Vol. 30, No. 16, (Dec, 2010) pp. 3363-3375, ISSN 0955-2219.

Mazaheri, M.; Simchi, A.; Golestani-Fard, F. (2008). Densification and graingrowth of nanocrystalline 3Y-TZP during two-step sintering. J Eur Ceram Soc, Vol. 28, No. 15, (Nov, 2008) pp. 2933-2939, ISSN 0955-2219.

Mecholsky Jr, J.J. (1995). Fracture mechanics principles. Dent Mater, Vol. 11, No. 2, (Mar, 1995) pp. 111-112, ISSN 0109-5641.

Miani, C.; Piconi, C.; Piselli, D.; Ponti, M. (1993). Prove sperimentali in vivo della zirconia in Implantologia Orale. Rev Ital Osseoint, Vol. 3, pp. 23-34, ISSN 2036$413 X$.

Miyazaki, T.; Hotta, Y.; Kunii, S.; Kuriyama, S. \& Tamaki, Y. (2009). A review of dental CAD/CAM: current status and future perspectives from 20 years of experience. Dent Mater, Vol. 28, No. 1 (Jan, 2009) pp. 44-56, ISSN 0109-5641.

Oden, A.; Andersson, M.; Krystek-Ondracek, I.; Magnusson, D. (1998). Five year clinical evaluation of Procera AllCeram crowns. J Prosthet Dent, Vol. 80, No. 4, (Oct, 1998) pp. 450-456, ISSN 0022-3913. 
Piconi, C.; Maccauro, G. (1999). Zirconia as a ceramic biomaterial. Biomaterials, Vol. 20, No. 1 (Jan, 1999) pp. 1-25, ISSN 0142-9612.

Piticescu, R.; Monty, C.; Millers, D. (2005). Hydrothermal synthesis of nanostructured zirconia materials: present state and future prospects. Sensors and Actuators B, Vol. 109, No. 1, (Aug, 2005) pp. 102-106, ISSN 0925-4005.

Quinn, J.B.; Sundar, V.; Lloyd, I.K. (2003). Influence of microstructure and chemistry on the fracture toughness of dental ceramics. Dent Mater, Vol. 19, No. 7, (Nov, 2003) pp. 603-611, ISSN 0109-5641.

Rahaman, M.N. (1995). Ceramic Processing and Sintering (2ed), Ed M. Becker, ISBN 9780824795733, New York.

Rashad, M.M.; Baioumy, H.M. (2008). Effect of thermal treatment on the crystal structure and morphology of zircon nanopowders produced three different routes. J Mat Proc Tech, Vol. 195, No. 1-3, (Jan, 2008) pp. 178-185, ISSN 09240136.

Scherrer, S.S.; Denry, I.L.; Wiskott, H.W. (1998). Comparasion of three fracture toughness testing techniques using a dental glass and a dental ceramic. Dent Mater, Vol. 14, No. 4, (Jul, 1998) pp. 246-255, ISSN 0109-5641.

Sõmiya, S.; Kumaki, T.; Hishinuma, K.; Nakai, Z.; Tokuji, A.; Suwa, Y. (1991). Hydrothermal precipitation of ZrO2 powder. Prog Crystal Growth Charact, Vol. 21, No. 1-4, (Oct, 1991) pp. 195-198, ISSN 0960-8974.

Sõmiya, T.; Akiba, T. (1999). Hydrothermal zirconia powders: a bibliography. J Eur Ceram Soc, Vol. 19, No. 1, (Apr, 1999) pp. 81-87, ISSN 0002-7820.

Sundh, A,; Sjörgren, G. (2008). A study of the bending resistance os implant-supported reinforced alumina and machined zirconia abutments and copies. Dent Mater, Vol. 24, No. 5, (Aug, 2008) pp. 611-617, ISSN 0109-5641.

Tartaj, J.; Tartaj, P. (2009). Two-stage sintering of nanosize pure zirconia. J Am Ceram Soc, Vol. 92, No. S1, (Jan, 2009) pp. 103-106, ISSN 0002-7820.

Thompson, J.Y.; Stoner, B.R.; Piascik, J.R. (2007). Ceramics for restorative dentistry: Critical aspects for fracture and fatigue resistance. J Mat Science Eng, Vol. 27, No. 3, (April, 2007) pp. 565-569, ISSN 0022-2461.

Tsalouchou, E.; Cattell, M.J.; Knowles, J.C.; Pittayachawan, P.; McDonald, A. (2008). Fatigue and fracture properties of yttria partially stabilized zirconia crown systems. Dent Mater, Vol. 24, No. 3, (Mar, 2008) pp. 308-318, ISSN 0109-5641.

Tsukada, T.; Venigalla, S.; Morrone, A.A.; Adair, J.H. (1999). Low temperature hydrothermal synthesis of yttrium-doped zirconia powders. J Eur Ceram Soc, Vol. 82, No. 5, (May, 1999) pp. 1169-1974, ISSN 0955-2219.

Vagkopoulou, T.; Koutayas, S.O.; Koidis, P. \& Strub, J.R. (2009). Zirconia in Dentistry: Part 1. Discovering the nature of an upcoming bioceramic. Eur J Esthet Dent, Vol. 4, No. 2, (Summer, 2009) pp. 130-151, ISSN 1862-0612.

Vigolo, P.; Fonzi, F.; Majzoub, Z.; Cordioli, G. (2006). An in vitro evaluation of titanium, zirconia and alumina Procera abutments with hexagonal connection. Int J Oral Maxillofac Implants, Vol. 21, No. 4, (Jul-Ago, 2006) pp. 575-580, ISSN 0882-2786. 
Wang, H.; Aboushelib, M.N.; Feilzer, A.J. (2008). Strength influencing variables on CAD/CAM zirconia frameworks. Dent Mater, Vol. 24, No. 5, (May, 2008) pp. 633638, ISSN 0109-5641.

Yildirim, M.; Edelhoff, D.; Hanisch, O.; Spiekermann, H. (2000). Ceramic abutments. A new era in achieving optimal esthetics in impalnt dentistry. Int J Periodontics Rest Dent, Vol. 20, No. 1, (Feb, 2000) pp. 81-91, ISSN 0198-7569.

Yildirim, M.; Fischer, H.; Marx, R.; Edelhoff, D. (2003). In vivo fracture resistance of imaplntsupported all-ceramic restorations. J Prosthet Dent, Vol. 80, No. 2, (Oct, 2003) pp. 325-331, ISSN 0022-3913. 


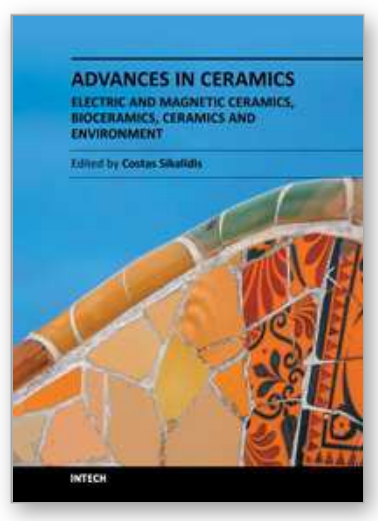

\author{
Advances in Ceramics - Electric and Magnetic Ceramics, \\ Bioceramics, Ceramics and Environment \\ Edited by Prof. Costas Sikalidis
}

ISBN 978-953-307-350-7

Hard cover, 550 pages

Publisher InTech

Published online 06, September, 2011

Published in print edition September, 2011

The current book consists of twenty-four chapters divided into three sections. Section I includes fourteen chapters in electric and magnetic ceramics which deal with modern specific research on dielectrics and their applications, on nanodielectrics, on piezoceramics, on glass ceramics with para-, anti- or ferro-electric active phases, of varistors ceramics and magnetic ceramics. Section II includes seven chapters in bioceramics which include review information and research results/data on biocompatibility, on medical applications of alumina, zirconia, silicon nitride, $\mathrm{ZrO} 2$, bioglass, apatite-wollastonite glass ceramic and b-tri-calcium phosphate. Section III includes three chapters in applications of ceramics in environmental improvement and protection, in water cleaning, in metal bearing wastes stabilization and in utilization of wastes from ceramic industry in concrete and concrete products.

\title{
How to reference
}

In order to correctly reference this scholarly work, feel free to copy and paste the following:

Cláudia Angela Maziero Volpato, Luis Gustavo D’Altoé Garbelotto, Márcio Celso Fredel and Federica Bondioli (2011). Application of Zirconia in Dentistry: Biological, Mechanical and Optical Considerations, Advances in Ceramics - Electric and Magnetic Ceramics, Bioceramics, Ceramics and Environment, Prof. Costas Sikalidis (Ed.), ISBN: 978-953-307-350-7, InTech, Available from: http://www.intechopen.com/books/advances-inceramics-electric-and-magnetic-ceramics-bioceramics-ceramics-and-environment/application-of-zirconia-indentistry-biological-mechanical-and-optical-considerations

\section{INTECH}

open science | open minds

\section{InTech Europe}

University Campus STeP Ri

Slavka Krautzeka 83/A

51000 Rijeka, Croatia

Phone: +385 (51) 770447

Fax: +385 (51) 686166

www.intechopen.com

\section{InTech China}

Unit 405, Office Block, Hotel Equatorial Shanghai

No.65, Yan An Road (West), Shanghai, 200040, China

中国上海市延安西路65号上海国际贵都大饭店办公楼 405 单元

Phone: +86-21-62489820

Fax: $+86-21-62489821$ 
(C) 2011 The Author(s). Licensee IntechOpen. This chapter is distributed under the terms of the Creative Commons Attribution-NonCommercialShareAlike-3.0 License, which permits use, distribution and reproduction for non-commercial purposes, provided the original is properly cited and derivative works building on this content are distributed under the same license. 